\title{
Portrayal of Women Protagonists in the Selected Novels of Bharati Mukherjee
}

Sarika

Research Scholar

Baba Mastnath University

Rohtak, Haryana, India

sarika1527b@gmail.com

Abstract

Bharati Mukherjee is a famous Indian born American non-fiction writer, short story writer and journalist. She is one of the well-known novelists of Indian Diaspora. Within a really short creative time, she has achieved enviable position in the field of English literature. In her works, she has very well depicted the Indian immigrant experience of her women characters both in her novels and short stories. In her works, she talks about the lives of Indian women immigrants in the U.S.A and their journey of transformation and adjustment of their lives and personalities. She tries to explore the themes of immigration as well as transformation. She portrays the various phases of her characters such as the phase of expatriation, the phase of transition and phase of immigration. She very well depicts how the cultural clash or cultural conflict between the west and the east leads to the psychological crisis in the minds of her women characters. In her novels, she has given importance to the feministic perspective of her women characters. Her women characters are the protagonist and hero of the novels. She has tried to portray how her female characters sacrifice their dreams, hopes, desires, wishes, what the various problems, fear, torture they face, and how they finally do their best to overcome from all the hurdles. She has drawn her female characters in various situations and circumstances. 
Kerwords: Feminstic Perspective, Bharati Mukherjee, Immigrants, Immigration, Expatriation. Introduction

Bharati Mukherjee is an Indian - American- Canadian novelist and short story writer. She was born on July 27, 1940 in Calcutta (now Kolkata), Bengal (now West Bengal), India in a wealthy Indian Hindu Bengali Brahmin family. In her novels, she has focused focus on the roles of women in different circumstances. Most of her women characters are sensitive creatures that are in search of both personal as well as cultural identity. They face various psychological conflicts in their process of immigration. Or we can say that in their process of immigration, they become the victims of psychological conflicts. The conflict of culture between the mother culture of the protagonist and the adopted culture of the protagonist leads the psychological conflict in the mind of the protagonist.

A woman performs various roles in her life. She plays the role of daughter, sister, wife, mother and so on. She is the only person who is responsible for tying the whole family in one single thread. She spends her whole life in the service of others. But she is never considered as an individual. The novelist goes beyond all the traditional roles of women and tries to portray her woman character as an individual who is independent and who has free will. She is of the opinion that woman needs to break all the shackles and come out of her traditional shell and should speak against the old fashioned patriarchal system. If they want to establish themselves in the society, then they need to develop their identity. For that, it is very necessary to break the chains of old traditions and culture. Mukherjee's women characters are the real champions in their battle of life. They do not allow the various troubles and impediments of life to stop them from being jolly and happy in their life. They are the women of strength and undaunted will. They try their best to come out of their despondent situation and condition. By resolving the various problems, they explore and evolve to new heights. 
In her works, she has dealt with the various themes such as search for identity, immigration, diaspora, Indianness, expatriation, transformation, acculturalization, Americanization, assimilation, etc. There is a strong connection between the experience and journey of women characters and the various themes in the novels. These themes perform vital role and help in the psychoanalytic study of women characters in the novels of Bharati Mukherjee.

Bharati Mukherjee's first novel, The Tiger's Daughter, deals with the story of Tara who is main protagonist of the novel. In this novel, the novelist has tried to highlight the protagonist's feeling of alienation. The story of the novel is somewhat related to Mukherjee's and her sisters' own story who went to America to study. In the novel, we witness that Tara comes back to her native country India after living and spending seven years in the United States of America. She comes back to India without her husband. When she arrives at the airport, she is little bit uncomfortable with the response and behaviour of her relatives. Her relatives are quite shocked and unhappy with Tara because she has come all alone without her husband David. They cannot digest that she is not accompanied by her husband. As per the Indian tradition and custom, a woman is supposed to be accompanied by her husband. She is not allowed to travel all alone just like Tara. They believe that she should be led by her husband wherever she goes and travels. If a woman lives alone, moves alone and travels alone then it is not accepted in our Indian society. Also according to Indian tradition and custom, one should marry in his/her own caste and country, especially a woman is supposed to follow it strictly. If one does not follow it then he/she is considered and treated as a sinner and an outcast.

"Perhaps her mother, sitting serenely Before God on a tiny rug, no longer loved her either. After all Tara had willfully abandoned her cast by marrying a foreigner. Perhaps her mother was offended that she, no longer a 
real Brahmin, was constantly in and out of this sacred room, dipping like a crow."(Mukherjee 50)

The protagonist Tara violates the rules and regulations framed by the patriarchal society in a country like India. Tara breaking all the rules and regulations dares to marry a man who is a foreigner and who does not belong to her caste. The man whom she marries is a Jew. She marries him forgetting her caste, religion and nativity. Here in the novel, the novelist has criticised the conservative ideology and attitude of the people in Indian who go crazy and mad for foreign commodities, clothes and other various things. But the same people will never agree the marriage to a foreigner. Tara feels isolated and alienated even in her own country. Even in the presence of her own mother, she feels isolated.

"For year she had dreamed of this return to India......But so far the return had brought only wounds. First the corrosive hours on Marin Drive, then the deformed baggers in railway station and now the inexorable train ride steadily undid what strength she had held in reserve." (Mukherjee 25)

She is both mentally and emotionally turbulent inside. She finally decides to leave and move back to the USA. In this novel, the novelist has brought into the light the feeling of isolation and alienation of Tara.

Mukherjee's second novel Wife is the story of Dimple Dasgupta who is a wife in this novel. She is not happy and satisfied with her life as a wife, so she really wants to break through the conventional role, image or taboo of a typical Indian wife. Dimple is a young Bengali girl who carries many dreams regarding her marriage and her life after marriage. As a result she impatiently and eagerly waits for her marriage to happen. She is finally married to Amit Basu. Her husband is expected to immigrate to America after marriage. So she starts weaving dreams about her new life with Amit in America. As a wife she is always supposed and expected to just fulfil the role of an ideal wife just like any typical ideal Indian wife. 
Various circumstances and conditions result in building frustration in Dimple. Dimple does not like her husband and his typical behaviour. Her husband wants her to act as submissive and docile wife. He does not understand Dimple, her emotions, feelings, pains etc.

"He never thought how hard it was for her keep quiet and smile thought she was falling apart like a very old toy that had been played with, sometimes quite roughly by children who claimed to love her.” (Mukherjee 212)

She just hates him. She is only needed by him to fulfil his sexual needs and desire. She gets so much mentally and psychologically upset that she dares to murder her own husband.

M.Rajeshwar in his work discusses about the psychological conflicts and traumas of the characters of the novels. He says;

"the characters are therefore shown grappling on one hand with the psychic conflicts of personal origin. These conflicts and traumas become too pronounced at a particular point of time in their life when a part of their psychic apparatus refuses to submit to several hostile cathexes they manifestly display three distinct tendencies: some move from neurosis to psychosis, others arise at a compromise solution for their problems and yet another group sets out to become compulsive idealists because they find the realities of life too harsh or repulsive to put up with.” (Rajeshwar, 142)

In the end of the novel, she stabs her husband seven times. Stabbing her husband seven times can be viewed as if she is trying to free herself from the marriage bond. And after murdering him, she also commits suicide.

Third novel is one of Bharati Mukherjee's most famous and well known novels, Jasmine. It is Mukherjee's one of the most accomplished novels. The novel tells the story of the protagonist's adaptation and not a defeat. The novel revolves around a rural Punjabi girl 
named Jyoti. The tension in the novel begins when the astrologer gives his prediction about the widowhood of Jyothi.

Jyothi is married to Prakash who is both enthusiastic as well as energetic. Her married life with Prakash goes smoothly without any kind of issues. As a wife, she fulfils all the expectations of her. Like a good Indian wife, she does everything a wife is supposed to do in her marriage. She is given another name and called as Jasmine. She takes pleasure in sharing the dreams and ambition of her husband. She is now looking forward to move to the land of hopes and many opportunities, America.

But on the day of departure, her husband is murdered. As a result, all her hopes and dreams get shattered. The protagonist does not lose hope and decide to move to America alone in order to fulfil the dreams and mission of her deceased husband. During her voyage, she is molested by the captain of the ship. In return, she murders him. Jasmine's act of murdering the captain fills her with confidence and courage which help her to face various problems, violence and atrocity in America. In America, she does not miss a single opportunity to be a part of the new foreign land. She learns to walk and talk like the Americans do.

In a refugee home, Jasmine has become Jase now. When the novel ends, Jase kills Sukhwinder who is the murderer of her husband, Prakash. The various roles played by Jasmine in this novel, highlights the power and strength of Indian woman who can destroy and fight against all the evil forces in her path. She is successful in breaking all the shackles and ties gender, caste, family and religion. She is an adaptor, fighter and survivor. She learns to live and survive for herself. She achieves success in carving all new life for herself in a foreign land. She can easily take a stand against all the hostile and unfavourable situations and circumstances. She is a winner in real sense. She breaks all the shackles of family, caste, 
gender and religion. She learns to live not for others but for herself. She gives the first priority to herself.

Bharathi Mukherjee's novel Desirable Daughters deals with the story of three sisters; Padma, Parvathi and Tara. The novel has some autobiographical touch as well. To some extent, it seems to be the story of the novelist herself and her sisters. Their names are the symbolic names of Shakti, Goddess of Hindu. The three sisters belong to a traditional Bengali Brahmin family. They are the grand daughters of Jai Krishna Gangooli and daughters of Motilal Bhattacharya. It is the story of immigrants. The novel deals the attitude of these three sisters and their different ways of dealing and handling the problems and situations they face in their journey. They are the mixed combination of modern outlook and traditional outlook. The title of the novel highlights the kind of daughter every parent want and would be always proud of. Tara is the narrator of the novel. Padma is an immigrant in New Jersey. Parvathi lives in Bombay and marries with the love of her own choice. Both the sisters, Padma and Parvathi are proud of their choices and do not regret their decision. Tara is married to Bishwapriya Chatterjee. She does not find happiness in her arranged marriage with her husband. She realizes that something is lacking in her married life. So she decides to step out of her traditional married life and applies for divorce. The divorce settlement takes place and Tara sends her son to her husband. She works in a pre-school as a volunteer. She is in love with Andy and enjoys her life with him. But things change after the unexpected blasting of the bomb and then Tara's real love for her husband comes out. She decides to move to her native land; India in search of solace and comfort. After coming back to her own country, she finally feels at home. She comes back to her father's home where she achieves peace and calmness. 
Mukherjee's novel The Holder of the World appeared in 1993. In this novel, the novelist has presented self-confidence and individuality through her central figure of the novel, Hannah. The main protagonist of the novel is Hannah Easton. She takes birth in Massachusetts. Later on she travels to India. It is a journey of Hannah. On her arrival in India, she comes in contact with some Indian lovers. Later on she meets a king who gifts her diamond .It is the tale of dislocation, probably of Hannah's. During her journey, she gets a chance to recognize her true self. Later on, she moves back to her native country. She has not reformed during her physical journey. She has now become a rebel who lives on the fringes of the society.

Bharati Mukherjee in her novel, Leave it to me, tries to explore the issues of culture and identity through her protagonist from a fresh angle. It is the story of Debby Di Martino. She is also called as Debi. She is a young woman who grows in a middle class family in Schenectady, New York. As a baby, she was abandoned by her Eurasian father and American mother in India. Di Martinos took her from the Catholic orphanage. She seeks revenge on her hippie parents who abandoned her. The story of the novel reveals the ungrateful dealings of Debi with her adoptive parents who are kind and a vengeful search for her real parents (described as a murderer and a flower child). The search for her real parents takes Debi to San Francisco. In San Francisco, she starts a new life as Devi Dee and sheds her old name and identity. Along with old name and identity, she also leaves behind her old conventions. Here in the new place, she carries on her hunt for her real mother who gave her life. This hunt of Devi leads her into a confrontation with the least expected demon. In her novel, Mukherjee highlights the conflict between the two worlds; the Eastern world and the Western world. She also throws light at mother-daughter relationships through the both emotional as well as political involvement of Debi in her quest for revenge. 
Mukherjee's latest novel is Miss New India. Anjali Bose is the protagonist in the novel Miss New India. She is born in a traditional lower middle class family. In Miss New India, the protagonist Anjali is a role model to many young girls in India who are in search of achieving great position and place. In a journey of reinventing herself, Anjali faces many ups and downs in metropolitan and high class city. In this novel, the novelist has very well pictured the struggle and liberation generally faced by girls in India in order to achieve something great and big. In this novel, the protagonist achieves great place because she carries strong will and determination in her psyche. It is the result of her positive psychology which provides her confidence and courage to face problems and difficulties. With her strong determination and will power, she climbs the ladder of success and fame. She achieves both name and fame. With the optimization of each and every occurrence in her life, she is successful in climbing the ladder of her dreams. Her optimized psyche helps her in acquiring a new identity.

In her novels, Bharati Mukherjee has tried to show the transformation of her women protagonists. She has thrown light on the long and constant struggle of her women characters against various kinds of emotions like frustration, passivity and suppression. The reader can clearly notice that in the process of their long and constant struggle, the female characters polish themselves and achieve perfection and also learn to play the game of life according to their wishes, and rules. Mukherjee's protagonists prove that they capable enough to shape their destiny themselves. Her protagonists, who are once oppressed and suppressed, try their best to break all the rules and regulations imposed upon them and come out of the shell of the traditional patriarchal system. They turn all the stones to establish their own identity. They try hard to establish themselves as individuals. Mukherjee's are capable to overcome all the difficulties and trials, restrictions. They explore the new paths and ways and create their own individual identity in the society. 
Bharati Mukherjee's women characters are modern, life-like and real. Through the psyche of her women protagonists, the novelist has tried to provide a real and authentic experience of the two different worlds, the Indian world on the one side and the Western world on the other side.

The women characters differ in The Tiger's Daughter and Wife from the other women characters in later novels of Bharati Mukherjee. But they all struggle very hard to adapt to reality in some way or other. Also they fail at some point and as a result they easily get depressed. In Jasmine, The Holder of the World and Leave it to Me, women characters seem to achieve their desired independence, freedom and self-assurance. They come to realize that if they really want to survive then they need to change and adapt themselves according to the present circumstances and environment. The protagonists in Desirable Daughters, The Tree Bride and, Miss New India come across various problems and difficulties in their life but they pass through them with their optimistic approach and outlook to life. Mukherjee's women characters struggle really hard in order to adapt to reality.

Bharathi Mukherjee has successfully depicted the expectations, dreams and desires of women in India through the portrayal of her protagonists who carry the dream of living and experiencing native culture and tradition in the foreign land. They generally feel alienated and isolated from their home, parents, families, tradition and culture. They keep on feeling and experiencing that they are missing something in their lives. Their lives come to an end with a sense of grief and loss. They always remain in a state of confusion. And try various ways to come out of their confusing state. The novels of Mukherjee depict personal difficulties of being caught between two worlds, homes and cultures. 


\section{Works Cited}

Mukherjee, Bharati. The Tiger's Daughter. Houghton Mifflin,1971.

Mukherjee, Bharati. Wife. Penguin Books,1980.

Mukherjee, Bharati. Jasmine. Penguin Books ,1990.

Mukherjee, Bharati. The Holder of the World. Fawcott Books, 1993.

Mukherjee, Bharati. Desirable Daughters. Rupa Publications India Private Limited, 2002.

Mukherjee, Bharati. The Tree Bride. Rupa Publications India Private Limited, 2004.

Mukherjee, Bharati. Miss New India. Rupa Publications India Private Limited, 2011.

Rajpal and Asnani. Identity Crisis in the Nowhere Man and wife in Quest for Identity in Indian English Part I: Fiction. Bahri Publications, 1992.

Rajeswar, M. The Inner World of Indian Women: Neurotic characters of Indian Women Novelists ] in Feminism and Literature. Prestige Books. 